\title{
Peta Penelitian Hukum Ekonomi Syari'ah pada Fakultas Syari'ah dan Hukum UIN Raden Fatah Palembang
}

\section{Yono Surya}

Fakultas Syariah dan Hukum

Universitas Islam Negeri Raden Fatah Palembag, Indonesia

Email: yonosurya_uin@radenfatah.ac.id

\begin{abstract}
Abstrak
Asumsi dialogis yang dimunculkan bahwa di ranah Fakultas Syari'ah membicarakan hukum, sementara Fakultas Ekonomi Dan Bisnis Islam pada ranah praktisi. Berdasarkan data observasi awal dengan menilai visi pada program studi Hukum Ekonomi Syari'ah dan program studi Ekonomi Islam pada 2 Fakultas yang berbeda dalam satu universitas diketahui bahwa keduanya berangkat dari pengembangan Ilmu Ekonomi Islam untuk pemenuhan kebutuhan hidup umat manusia secara komprehensif, baik material maupun moral dan spiritual serta menjaga keberlangsungannya dengan pendekatan analisis komparatif maupun integratif dengan pluralisme metodologi, baik moral, fikih, ekonomi, bisnis dan keuangan. Khusus di Universitas Islam Negeri Raden Fatah, keberadaan Fakultas Ekonomi dan Bisnis Islam merupakan pengembangan dari Jurusan Ekonomi Islam dan Diploma Perbankan pada Fakultas Syari'ah dan Hukum.
\end{abstract}

Kata Kunci: Hukum Ekonomi Syari'ah, Ekonomi Islam

Penelitian dilakukan dengan beberapa alasan, yaitu: Pertama, terbitnya Peraturan Direktur Jenderal Pendidikan Islam Nomor 1429 Tahun 2012 yang salah satu peraturan tersebut terjadi perubahan numenklatur Program Studi muamalah berubah menjadi program studi Hukum Ekonomi Syari'ah. Kedua, hasil penelitian untuk menjelaskan sistematis ilmiah atas perbedaan signifikan program studi Hukum Ekonomi Syari'ah pada Fakultas Syari'ah dan Hukum dengan program studi ekonomi Islam pada Fakultas Ekonomi dan Bisnis Islam.

Selanjutnya hasil studi ini berguna untuk melacak sejarah perkembangan Program Studi bidang ekonomi yang berkembang di Fakultas Syari'ah dan Hukum yang pada awalnya Program Studi Perdata Pidana Islam (PPI), kemudian menjadi Program studi Muamalah dan terakhir menjadi program studi hukum ekonomi Syari'ah berdasarkan nomenklatur di UIN Raden Fatah Palembang. Disamping itu berguna untuk memetakan wilayah kajian antara 2 program studi yang sama sama 
berbasis "ekonomi Syari'ah yang berada pada Fakultas Syari'ah Dan Hukum dengan Ekonomi Islam Fakultas Ekonomi Dan Bisnis Islam (FEBI).

Asumsi dialogis yang dimunculkan bahwa di ranah Fakultas Syari'ah membicarakan hukum, sementara Fakultas Ekonomi Dan Bisnis Islam pada ranah praktisi. Pertanyaan mendasar kemudian "Bagaimana titik singgung yang menjelaskan bahwa ini bagian kajian hukum dan ini adalah bagian praktisi disaat yang bersamaan fakultas syari'ah membahas kajian praktisi ekonomi dan Fakultas ekonomi Islam mengkaji hukum? Mengapa terjadi perbedaan antara ekonomi Syari'ah dan ada ekonomi Islam? Penelaahan ilmiah dalam penelitian ini menjadi jawaban atas asumsi tersebut.

Berdasarkan data observasi awal dengan menilai visi pada program studi Hukum Ekonomi Syari'ah dan program studi Ekonomi Islam pada 2 Fakultas yang berbeda dalam satu universitas diketahui bahwa keduanya berangkat dari pengembangan Ilmu Ekonomi Islam untuk pemenuhan kebutuhan hidup umat manusia secara komprehensif, baik material maupun moral dan spiritual serta menjaga keberlangsungannya dengan pendekatan analisis komparatif maupun integratif dengan pluralisme metodologi, baik moral, fikih, ekonomi, bisnis dan keuangan. Khusus di Universitas Islam Negeri Raden Fatah, keberadaan Fakultas Ekonomi dan Bisnis Islam merupakan pengembangan dari Jurusan Ekonomi Islam dan Diploma Perbankan pada Fakultas Syari'ah dan Hukum.

Hal urgen juga adalah bagaimana menyelesasiakan sengketa ekonomi Syari'ah yang berimplikasi pada kepercayaan publik. Asumsi langkah adalah penguatan kapasitas hakim, khususnya hakim peradilan agama dalam mengadili sengketa ekonomi syari'ah yang mulai jadi kewenangan peradilan agama. Penyiapan Sumber Daya Manusia yang memiliki kompetensi dalam bidang ekonomi syari'ah, baik bank syariah maupun lembaga keuangan syari'ah. Ini artinya alumni Fakultas Syari'ah dan Hukum dapat dipersiapkan menjadi hakim peradilan agama yang mampu menangani sengketa perbankan dan ekonomi syariah secara adil dan profesional.

Hal tersebut juga menjadi pertimbangan menjadikan program studi hukum ekonomi syari'ah untuk memetakan mata kuliah yang sejatinya berimplikasi pada hal tersebut, dan tidak mengajarkan pada pelaku usaha dan enterpeneuer. Dalam penelitian ini dua rumusan masalah utama yaitu (1) Bagaimana konsep dasar Epistimoogi Program Studi Hukum Ekonomi Syari'ah pada Fakultas Syari'ah dan Hukum UIN Raden Fatah dalam Mengembangkan kajian Ilmiah?; (2)Bagaimana 
membangun keselarasan pembidangan penelitian pada Program Studi Hukum Ekonomi Syari'ah pada Fakultas Syari'ah?

Penamaan perguruan tinggi mengacu kepada hasil pertimbangan peta pendidikan pada jenjang perguruan tinggi yang dilandaskan pada aspek pembidangan keilmuwan terkait erat dengan nomenklatur yang diajukan untuk pendirian Perguruan Tinggi Agama Islam. Dengan merujuk kepada UU No. 12 Tahun 2012 tentang Pendidikan Tinggi, Peraturan Pemerintah Nomor 17 Tahun 2010 tentang Pengelolaan dan Penyelenggaraan Pendidikan sebagaimana telah diubah dengan Peraturan Pemerintah Nomor 66 Tahun 2010 dan Peraturan Menteri Agama No. 36 Tahun 2009 tentang Pembidangan Ilmu dan Gelar Akademik pada Perguruan Tinggi Agama

Islam dan Peraturan Direktur Jenderal Pendidikan Islam Nomor: 1429 Tahun 2012 tentang Penataan Program Studi diPerguruan Tinggi Agama Islam.

Dalam penataan Program Studi di Perguruan Tinggi Prodi Muamalah dibuat dalam kurung (Hukum Ekonomi Syari'ah). Dalam perspektif ini Fakultas Syariah dan Hukum Universitas Islam Negeri (UIN) Raden Fatah Palembang melaksanakan rapat kerja dengan tema Upaya mewujudkan Program Studi yang Berkualitas. Upaya tersebut sejalan dengan pembaharuan pasca penetapan ditetapkan UU No. 14 Tahun 1970 dalam dua prinsip dasar yaitu (1) peradilan agama sebagai salah satu lingkungan badan peradilan negara disamping tiga badan peradilan lainnya (peradilan umum, peradilan militer, dan peradilan tata usaha negara; (2) penghapusan sistem "fiat eksekusi" oleh peradilan umum atas putusan peradilan agama.

Selanjutnya UU No. 7 Tahun 1989. Pasal 49 UU No. 7 Tahun 1989, menyebut enam kekuasaan peradilan agama (perkawinan, kewarisan, wasiat, hibah, wakaf, zakat) yang diurai dalam penjelasan pasal tersebut menjadi 22 macam kewenangan. Dalam Undang-Undang Perubahan UU No. 3 Tahun 2006 wewenang yang diatur dalam Pasal 49 diperluas menjadi sembilan macam (perkawinan, waris, wasiat, hibah, wakaf, zakat, infaq, shadaqoh, dan ekonomi syari'ah). Tambahan baru adalah zakat, infaq, dan ekonomi syari'ah. Selain rincian 22 macam yang diatur dalam penjelasan, diuraikan pula mengenai "ekonomi syari'ah" yang meliputi sebelas macam wewenang (bank syari'ah, lembaga keuangan mikro syari'ah, asuransi syari'ah, reasuransi syari'ah, reksa dana syari'ah, obligasi syari'ah dan surat berharga berjangka menengah syari'ah, sekuritas syari'ah, pembiayaan syari'ah, pegadaian syari'ah, dana pensiun lembaga keuangan syari'ah, dan bisnis syari'ah). 
Disamping itu ditegaskan pula untuk dapat diangkat menjadi hakim salah satu nya sarjana syari'ah atau sarjana hukum yang menguasai hukum Islam. Hal tersebut juga menjadi bagian penting dalam penguatan program studi pada aspek penguasaan fikih, dan penelaahan melalui kitab kitab fikih klasik. Karena itu juga dalam pengembangan kurikulum kemahiran hukum juga dapat dikembangkan penelaahan kitab kitab fikih klasik. Dalam prospeknya dengan berbagai dinamika perkembangan hukum menjadikan Prodi Hukum Ekonomi Syariah memiliki peluang karena wewenang Pengadilan Agama dalam menyelesaikan sengekta mengenai "Ekonomi Syariah" yang meliputi sebelas macam wewenang (bank syari'ah, lembaga keuangan mikro syari' ah, asuransi syari'ah, reasuransi syari'ah, reksa dana syari'ah, obligasi syari'ah dan surat berharga berjangka menengah syari'ah, sekuritas syari'ah, pembiayaan syari'ah, pegadaian syari'ah, dana pensiun lembaga keuangan syari'ah,dan bisnis syari'ah).yang tentunya jurusan Prodi hukum ekonomi syariah yang lebih kompeten untuk memasuki persoalan tersebut (The right man on the right job).

\section{Peta Konsep Penelitian Ekonomi Syari'ah dan Ekonomi Islam}

Dalam konsep besar peta konsep penelitian terbagi dalam 2 katagori sebagaimana terlihat dalam tabel berikut

Tabel 1

Perbandingan Paradigma Kualitatif dan Kualitatif

\begin{tabular}{|l|l|}
\hline \multicolumn{1}{|c|}{ Paradigma Kualitatif } & \multicolumn{1}{|c|}{ Paradidma Kuantitatif } \\
\hline $\begin{array}{l}\text { Mengajurkan penggunaan metode } \\
\text { kualitatif }\end{array}$ & $\begin{array}{l}\text { Menganjurkan penggunaan metode } \\
\text { kuantitatif }\end{array}$ \\
\hline $\begin{array}{l}\text { Fenomelogisme dan verstehen } \\
\text { dikaitkan dengan pemahaman } \\
\text { perilaku manusia dari frame of } \\
\text { reference aktor itu sendiri }\end{array}$ & $\begin{array}{l}\text { Logika positivisme:"Melihat fakta atau } \\
\text { kasual fenomena sosial dengan sedikit } \\
\text { melihat bagi pernyataan subyektif } \\
\text { individu-individu" }\end{array}$ \\
\hline $\begin{array}{l}\text { Observasi tidak terkontrol dan } \\
\text { naturalistik }\end{array}$ & Pengukuran terkontrol dan menonjol \\
\hline Subyektif & Obyektif \\
\hline $\begin{array}{l}\text { Dekat dengan data: merupakan } \\
\text { perspektif "insider" }\end{array}$ & $\begin{array}{l}\text { Jauh dari data: data merupakan perspektif } \\
\text { "outsider" }\end{array}$ \\
\hline
\end{tabular}




\begin{tabular}{|l|l|}
\hline $\begin{array}{l}\text { Grounded, orientasi diskoveri, } \\
\text { eksplorasi, ekspansionis, deskriptif, } \\
\text { dan induktif }\end{array}$ & $\begin{array}{l}\text { Tidak grounded, orientasi verifikasi, } \\
\text { konfirmatori, reduksionis, inferensial dan } \\
\text { deduktif-hipotetik }\end{array}$ \\
\hline Orientasi proses & Orientasi hasil \\
\hline Valid: data "real, "rich, dan "deep" & Reliabel:data dapat direplikasi dan "hard" \\
\hline $\begin{array}{l}\text { Tidak dapat digeneralisasi:studi } \\
\text { kasus tunggal }\end{array}$ & Dapat digeneralisasi:studi multi kasus \\
\hline Holistik & Partikularistik \\
\hline Asumsi realitas dinamik & Asumsi realitis stabil \\
\hline
\end{tabular}

Tabel 2

Perbandingan Pemahaman Ekonomi Islam dan Ekonomi Syari'ah

\begin{tabular}{|c|c|c|}
\hline No & Ekonomi Islam & Ekonomi Syari'ah \\
\hline 1 & Berkaitan dengan norma & Berkaitan dengan hukum \\
\hline 2 & Ilmu normatif & Ilmu hukum \\
\hline 3 & $\begin{array}{l}\text { Praktik bank dan lembaga } \\
\text { keuangan }\end{array}$ & $\begin{array}{l}\text { Identifikasi ilmu hasil penafsiran } \\
\text { al-quran dan al-hadits, ilmu hasil } \\
\text { penafsiran ruang dan waktu, ilmu } \\
\text { yang mempunyai eksistensi } \\
\text { tertentu. }\end{array}$ \\
\hline 4 & $\begin{array}{l}\text { Suatu cabang pengetahuan yang } \\
\text { membantu merealisasikan } \\
\text { kesejahteraan manusia melalui } \\
\text { suatu alokasi dan distribusi sumber- } \\
\text { sumber daya langka yang seirama } \\
\text { dengan maqashid, tanpa } \\
\text { mengekang kebebasan individu, } \\
\text { menciptakan ketidakseimbangan } \\
\text { makroekonomi dan ekologi yang } \\
\text { berkepanjangan, atau melemahkan } \\
\text { solidaritas keluarga dan sosial serta } \\
\text { jaringan moral masyaraka }\end{array}$ & $\begin{array}{l}\text { Perbedaan pandangan para tokoh } \\
\text { ekonomi Islam menyangkut } \\
\text { pengertian ekonomi islam atau } \\
\text { pengertian ekonomi syariah pada } \\
\text { dasarnya berakar pada tiga masalah } \\
\text { utama yakni: Pertama, metodologi } \\
\text { yang di pakai dalam membangun } \\
\text { ekonomi Islam dan sistem ekonomi } \\
\text { Islam. Kedua, perbedaan } \\
\text { penafsiran konsep ekonomi seperti } \\
\text { penafsiran makna khilafah dan } \\
\text { implikasi kepemilikan. Dan ketiga, } \\
\text { perbedaan tafsiran bangunan sistem } \\
\text { ekonomi. }\end{array}$ \\
\hline
\end{tabular}




\begin{tabular}{|l|l|l|}
\hline 5 & $\begin{array}{l}\text { Ilmu pengetahuan sosial yang } \\
\text { mempelajari masalah-masalah } \\
\text { ekonomi rakyat yang diilhami oleh } \\
\text { nilai-nilai Islam }\end{array}$ & $\begin{array}{l}\text { Ekonomi yang berdasarkan pada } \\
\text { ketuhanan. Esensi sistem ekonomi } \\
\text { ini bertitik tolak dari Allah, tujuan } \\
\text { akhirnya kepada Allah, dan } \\
\text { memanfaatkan sarana yang tidak } \\
\text { lepas dari syari'at Allah. }\end{array}$ \\
\hline 6 & $\begin{array}{l}\text { Pengetahuan dan aplikasi ajaran- } \\
\text { ajaran dan aturan-aturan syariah } \\
\text { yang mencegah ketidakadilan } \\
\text { dalam pencarian dan pengeluaran } \\
\text { sumber-sumber daya, guna } \\
\text { memberikan kepuasan bagi } \\
\text { manusia dan memungkinkan } \\
\text { mereka melaksanakan kewajiban } \\
\text { mereka terhadap Allah dan } \\
\text { aktivitas perekonomian beserta } \\
\text { aturan-aturanna yang didasarkan } \\
\text { kepada pokok-pokok ajaran Islam } \\
\text { tentang ekonomi. }\end{array}$ \\
\hline
\end{tabular}

Dalam konteks peta penelitian hukum ekonomi syari'ah pada Fakultas Syari'ah Dan Hukum Universitas Islam Raden Fatah Palembang ditelaah dalam dua konsep dalam penelaahan ini yaitu KKNI dan Ilmu kesyaria'ahan. Secara konseptual, setiap jenjang kualifikasi dalam KKNI disusun oleh empat parameter utama yaitu (a) Ilmu pengetahuan (science), (b) pengetahuan (knowledge), (c) pengetahuan praktis (know-how), (d) keterampilan (skill), (e) afeksi (affection) dan (f) kompetensi (competency). Ke-enam parameter yang terkandung dalam masingmasing jenjang disusun dalam bentuk deskripsi yang disebut Deskriptor Kualifikasi. Dengan demikian ke-9 jenjang kualifikasi dalam KKNI memuat deskriptordeskriptor yang menjelaskan kemampuan di bidang kerja, lingkup kerja berdasarkan pengetahuan yang dikuasai dan kemampuan manajerial dan dinyatakan sebagai capaian pembelajaran.Penelaahan konsep didasarkan pada ranah substansi, struktur dan ranah hukum.

Sebagai sub sistem sosial, substansi hukum membangun aturan hukum berelasi dengan subjek hukum. Sementara struktur merupakan kelembagaan hukum dan kultur hukum berpandangan pada prilaku dan respon subjek hukum yang melaksanakan substansi hukum (Warassih, 2004, hal. 34). Sejalan dengan perkembangan bangsa Indonesia, subsatansi, struktur dan kultur merupakan warisan Belanda yang tidak menyentuh perkembangan perkembangan sosial yang terjadi di 
Indonesia, ditambah dengan moral hukum yang bersumber dari agama masih termarginal. Alih alih, ketegasan hukum belum menjadi momentum untuk penguatan bangsa.

Ripyal (2004, hal. 39) menjelaskan bahwa Indonesia belum memiliki hukum nasional yang mencerminkan moralitas bangsa yang mengikat seluruh masyarakat seiring antara des sein dan des sollen. Artinya secara des sollen Indonesia mempunyai hukum nasional yang berlaku di negara kesatuan republik Indonesia, namun secara des sein masih mengekpresikan pertanyaan mendasar apakah semua hukum yang berlaku sudah mencerminkan norma moral masyarakat Indonesia yang dijiwai oleh nilai-nilai religius. Daud Ali (1993, hal. 116) mengisyaratkan bahwa:

Substansi hukum nasional seharusnya mencerminkan nilai moral dan falsafah mayoritas bangsa Indonesia, yaitu Islam. Karena fakta histories menjelaskan hukum Islam bahkan termasuk aspek pidananya pernah berlaku di nusantara sampai datangnya penjajah Belanda. Demikian juga, pasal 29 UUD 1945, menjadi landasan konstitusional bagi keberlakuan hukum Islam Indonesia, sebagai hukum nasional, meskipun hanya mengikat ummat Islam saja

Selanjutnya syari'ah seperti dijelaskan pada bab sebelumnya secara etimologi berarti jalan menuju sumber air. Jalan menuju sumber air ini bisa berarti jalan kearah sumber kehidupan (Nabhan, hal. 10). Sedangkan secara etimologi syari'ah menurut Manna 'Qathan (hal. 77) adalah segala ketentuan Allah yang disyaria'tkan kepada hambanya yang mencakup aqidak, akhlak, ibadah maupun muamalah. Sementara, menurut Mahmud Syaltut, Syari'ah ialah: hukum - hukum yang digariskan Allah, atau dasar- dasar hukum yang digariskan Allah agar manusia dapat mempedomaninya dalam hubungan -hubungannya dengan Tuhan, hubungannya dengan sesama manusia, dan hubungnanya dengan alasan alam dan kehidupan" (Ash-Shidiqi, 1993, hal. 31).

Dari definisi diatas dapat disimpulkan bahwa Syari'ah itu identik dengan agama yang ajarannya meliputi aqidah, ahlak, ibadah, muamalah namun dalam perkembangannya. Pengertian syari'ah mengalami penyempitan makna hanya mengenai ketentuan Allah yang terkait dengan perbuatan praktis manusia seharihari baik dalam lapangan ibadah maupun muamalah. Berkaitan dengan hal ini, Faruq Nabhan seperti dikutip dari Hasanuddin menyatakan, "syari'ah mencakup aspek akidah, ahlak, dan muamalah, namun kadang kala syari'ah berkonotasi fikih". Selanjutnya, ketika kata syari'ah digandengkan dengan kata-kata ilmu sehingga 
menjadi ilmu syari'ah, maka disini syari'ah tidak lagi sekedar dipahami sebagai sebuah kumpulan ajaran- ajaran agama, tetapi lebih jauh lagi menjadi obyek sasaran penyelidikan ilmu. Oleh karena itu, ilmu syari'ah sebagaimana ilmu- ilmu yang lain memiliki komponen utama sebagai tiang penyangganya, yaitu komponen ontology, epitimologi, dan aksiologi (Junaidi, 2004, hal. 15).

Dalam penjelasannya, Hasanuddin menyebutkan bahwa komponen ontology ilmu syari'ah adalah objek yang menjadi sasaran penyelidikan ilmu ini, Yaitu norma- norma yang menagtur tingkah laku yang bersumber kepada al-Qur'an dan As-Sunnah maupun yang bersumber pada ijtihad. Sedangkan komponen epistimologi atau metode dan cara untuk mendapatkan ilmu syari'ah adalah melalui:metode bayani (penjelasan terhadap teks- teks nash), metode penalarananalogis (qiyas) terhadap konsep yang ada dalam nash (Al-Qur'an dan As-Sunnah) dengan kenyataan, dan metode istislahi yang merupakan bentuk penalaran hukum yang diasumsikan dari penarikan kebaikan dan penolakan kemudharatan atau merupakan penalaran hukum yang berlandaskan pada maqasid al- syari'ah (Ad-Dawalibi, hal. 442). Secara umum metode ilmu syari'ah tersistematir dalam ilmu ushul fikih (teori hukum, legal theory) dan ilmu qawaid fikihiyah (kaidah- kaidah hukum, legal maxim). Sementara komponenen aksiologi ilmu syari'ah adalah manfaat yang diperoleh dari ilmu syari'ah. Dalm hal ini ilmu syari'ah dapat digunakan untuk mengatur dan nmemelihara hubungan dengan Tuhan, sesama manusia, dan dengan alam. Oleh Karena itu,ilmu syari'ah mengandung nilai- nilai untuk memelihara hubungan vertical dan horizontal secara harmonis.

Kehadiran program studi Hukum Ekonomi Syari'ah Fakultas Syari'ah dan Hukum UIN Raden Fatah Palembang datang untuk memberikan kiprah dalam upaya memberikan nilai moral dan falsafah mayoritas agama bangsa Indonesia. disamping itu menjaga konsistensi atas berbagai produk hukum legislasi yang mengangkat hukum agama (Islam) menjadi hukum nasional. Dimulai dengan undang-undang perkawinan, undang-undang peradilan agama, undang-undang haji, sampai dengan undang-undang wakaf. Dalam kaitannya dengan ekonomi syariah, terakhir telah dibentuk Undang-Undang Nomor 38 Tahun 2008 tentang Bank Syariah, dan sekarang berbagai Undang Undang aktifitas ekonomi syari'ah.

Dalam dasar pencapaian pembelajaran mata kuliah khusus dinilai dari pemahaman mahasiswa teks berbahasa Arab, penguasaan berbagai sumber hukum positif dan hukum Islam, penguasaan metode istimbat hukum Islam tentang hukum ekonomi syariah, teori-teori hukum ekonomi syariah keluarga dan implementasinya 
di masyarakat, peguasaan atas tatacara hukum beracara di pengadilan agama, menguasai metode penyelesaian masalah melalui mediasi, menguasai landasan hukum keluarga baik dari peraturan perundang-undangan maupun kitab fikih. Capaian dasar ketrampilan dimana lulusan Prodi Hukum Ekonomi wajib memiliki keterampilan umum sebagai berikut:

a. Mampu menerapkan pemikiran logis, kritis, sistematis, dan inovatif dalam kontek pengembangan atau implementasi ilmu pengetahuan dan teknologi yang memperhatikan dan menerapkan nilai humaniora yang sesuai dengan bidang keahliannya

b. Mampu menunjukkan kinerja mandiri, bermutu dan terukur

c. Mampu mengkaji implikasi pengembangan atau implementasi ilmu pengetahuan dan teknologi yang memperhatikan dan menerapkan nilai humaniora sesuai dengan keahliannya berdasarkan kaidah, tata cara, dan etika ilmiah dalam rangka menghasilkan solusi, gagasan, desain atau kritik seni

d. Menyusun deskripsi saintifik, hasil kajiannya dalam bentuk skripsi atau laporan tugas akhir, dan mengunggahnya dalam laman perguruan tinggi

e. Mampu mengambil keputusan secara tepat, dalam konteks penjelasan masalah di bidang keahliannya berdasarkan hasil analisis informasi dan data

f. Mampu memelihara dan mengembangkan jaringan kerja dengan pembimbing, kolega dan sejawat baik di dalam maupun di luar lembaganya

g. Mampu bertanggungjawab atas pencapaian hasil kerja kelompok melakukan supervisi dan evaluasi terhadap penyelesaian pekerjaan yang ditugaskan kepada pekerja yang berada di bawah tanggungjawabnya

h. Mampu melakukan proses evaluasi diri terhadap kelompok kerja yang berada di bawah tanggungjawabnya dan mampu mengelola pembelajaran secara mandiri

i. Mampu mendokumentasikan, menyimpan, mengamanahkan, dan menemukan kembali data untuk menjamin kesahihan mencegah plagiasi;

j. Mampu memanfaatkan teknologi informasi komunikasi untuk pengembangan keilmuan dan kemampuan kerja.

Capaian Pembelajaran Bidang Keterampilan Khusus Program Studi Hukum Ekonomi meliputi (1) ketrampilan merumuskan keputusan hukum positif dan hukum Islam terintrgrasi; (2) ketrampilan mengkomunikasi keputusan hukum 
ekonomi syariah kepada masyarakat secara umum; (3) ketrampilan menganalisis putusan pengadilan agama maupun pengadilan umum; (4) ketrampilan melakukan konsultasi, advokasi dan mediasi terkait dengan masalah dalam hukum ekonomi syariah; (5) ketrampilan membuat berita acara perkara dalam persidangan dan dalam penyelesaian hukum lainnya, menyusun replik dan duplik; (6) ketrampilan memahami berbagai aspek hukum dari bank syariah, lembaga keuangan mikro syariah, asuransi syariah, reasuransi syariah, reksadana syariah, obligasi syariah dan surat berharga berjangka menengah syariah, sekuritas syariah, pembiayaan syariah, pegadaian syariah, dana pensiun lembaga keuangan syariah, dan bisnis syariah.

\section{Membangun Keselarasan Pembidangan Penelitian pada Program Studi Hukum Ekonomi pada Fakultas Syari'ah dan Hukum}

Membangun keselarasan diperlukan satu nilai historis perjuangan untuk memberlakukan nilai syari'ah di Indonesia seiring pluralitas hukum yang berlaku yaitu hukum Barat (terutama warisan Belanda) dan hukum adat. Politik Hukum Nasional terutama masa Soeharto pada fase perangkulan umat Islam memberikan peluang kepada hukum Islam untuk menjadi hukum nasional atau setidaknya menjiwai hukum nasional (Junaidi, 2008). Pasca reformasi telah banyak undangundang produk legislasi yang mengangkat hukum agama (Islam) menjadi hukum nasional. Dimulai dengan undang-undang perkawinan, undang-undang peradilan agama, undang-undang haji, sampai dengan undang-undang wakaf.

Dalam kaitannya dengan ekonomi syariah, terakhir telah dibentuk UndangUndang Nomor 38 Tahun 2008 tentang Bank Syariah, berbagai aturan sudah diundangkan seperti UU Sukuk, UU Asuransi Syariah, UU Pasar Modal Syariah. Ditambah lagi dengan eksisnya badan badan kesyari'ahan di Indonesia yang menjadi lembaga kesyaria'ahan, seperti Perbankan syariah, Asuransi syariah, Pegadaian syariah, Pasar Modal syariah, BMT (Baitul Mal wat Tamwil) dan ditambah dengan Dewan Syariah Nasional dan Dewan Pengawas Syariah, dan Badan Arbitrase Syariah Nasional (BASYARNAS), serta badan lainnya yang berorientasi kepada Syari'ah.

Dari berbagai hal tersebut alumni pada program studi Hukum Ekonomi Islam (awalnya dikenal dengan "muamalah") dapat mengisi berbagai komponen tersebut termasuk peradilan agama sebagai perangkat hukum ekonomi Syari'ah. Selanjutnya dalam penelaahan penelitian mahasiswa program studi Hukum Ekonomi Syari'ah dapat membangun keselarasan dan perbedaan penelitian dalam 
tataran filosofis dan aplikasi dalam perbankan, bentuk sistem keuangan seperti penafsiran mengenai riba yang berimplikasi pada praktik menggunakan intrumen berbasis pembagian keuntungan dan kerugian bukan pada bunga. Maka berbagai rumusan penelitian seperti (1) bagaimana prinsip-prinsip ekonomi syariah ditranformasi dalam undang-undang Perbankan untuk mencapai tujuan hukum Islam; (2) Bagaimana pelaksanaan peraturan perundang-undangan perbankan syariah di Indonesia?

Bila dilihat dari realitas perubahan kewenangan di Pengadilan Agama terutama mengenai ekonomi syari'ah, maka peluang program studi Hukum Ekonomi pada Fakultas Syari'ah dan Hukum UIN Raden Fatah memiliki banyak kesempatan peluang kerja di bandingkan jurusan yang lain di Fakultas Syariah sebab sangat di butuhkan di lingkungan peradilan Agama disebabkan sudah mulai banyak perkara di Pengadilan Agama mengenai sengketa Ekonomi hingga ke kasasi.

Selanjutnya dalam ranah aksiologi syari'ah, penelitian hukum ekonomi Syari'ah dibagi menjadi: 1) al- Ahkam al- I'tiqadiyah (hukum- hukum yang berhubungan dengan keyakinan guna menjalin hubungna yang dekat antara manusi dengan Tuhannya), 2) al- Ahkam al- Khuluqiyah (hukum- hukum yang berkaitan dengan ahlak yang mengatur bagaimana manusia harus berbuat kebaikan dan menjauhi kejelekan baik pada Tuhan, pada diri sendiri, sesama manusia, dan pada mahluk selainnya), 3) al-Ahkam al-'Amaliyah ( hukum- hukum praktikal yang mengatur perbuatan, ucapan, perkataan, dan berbagai tindakan hukum seseorang). Hukum amaliyah ini dibagi dua: 'ubudiyyah (ibadah, seperti shalat, zakat, puasa dan haji dll) dan mu'amalat (hubungan sosial) (Junaidi, 2004).

Hukum muamalah menurut Kamil Musa (1989, hal. 84) dalam al- Madhkal ila al- Tasyri' al- Islami. Dibagi menjadi dua bagian: yaitu mu'amalat al-khas dan mu'amalat al- 'am. Mu'amalat khas adalah hal- hal yang berkaitan dengan kegiatan ekonomi Islam, misalnya: jual beli, pegadaian, asuransi, syirkah, hiwalah, dlaman, qiradl, mudharabah, murabahah, dan lain sebaginya. Sedangkan mu'amalat al'amm terbagai menjadi tiga, yakni: 1) al-Ahwal al-Syakhsiyah (hukum keluarga, termasuk di dalamnya adalah: perkawinana, warisan, wasiat, wakaf, dan hibah, 2) jinayah (hukum pidana Islam), termasuk di dalamnya adalah: pembunuh, pencurian, perampokan, minum- minuman keras, zina, menuduh zina, dan 3 ) al-Syakhsiyah, termasuk di dalamnay adalah: siyasah dusturiyah (administrasi negara), siyasah dauliyah (hubungan antar negara/internasional), dan siyasah maliyah (politik ekonomi Islam). Semntar Wahbah Zuhaily menambahkan dengan yang ke 4) yaitu: 
Ahkam al- murafa'at al-ijra 'at madaniyah au al-jinaiyah (hukum acara) (Zuahily, 1987, hal. 439). Merujuk pembidangan ilmu-ilmu syari'ah tersebut diatas, maka ilmu- ilmu syari'ah yang bisa dikembangkan oleh Fakultas Syari'ah dan hukum pada bidang mu'amalat khash dan mua'malat aam. Juruan Hukum Ekonomi Syari'ah mengembangkan bidang mu'amalat al- Khas.

Upaya mengembangkan Ilmu-Ilmu syari'ah, selain melalui pembukaan berbagai jurusan/program studi di fakultas Syari'ah, juga perlu dilakukan dengan membentuk wadah pengembangan, sebab ilmu-ilmu syari'ah yang ada sekarang umumnya merupakan hasil formulasi para ulama pada abad-abad pertengahan yang dari segi kondisi sosial kultural dan peradabannya telah jauh dengan zaman sekarang. Oleh karena itu, untuk mengembangkan ilmu-ilmu syari'ah agar selalu relevan dengan tuntutan zaman dan kondisi sosial kultural dengan tetap mengedepankan prinsip-prinsip ilmu syari'ah baik pada tataran ontology, epistimologi maupun.

Diantara kegiatan yang menjadi bahan kajian adalah mengenai kurikulum ilmu- ilmu syari'at yang dikembangkan di fakultas Syari'ah melalui jurusan atau program studinya. Dalam kaitan ini, penyusunan kurikulum ilmu- ilmu syari'at tentu saja harus memperhatikan "kerangka bangun (komponen ilmu)" ilmu- ilmu syari'at secara utuh dengan memperhatikan juga kekhususan ilmu syri'at yang hendak dikembangkan masing-masing jurusan atau program studi berbasis KKNI

KKNI merupakan perwujudan mutu dan jati diri bangsa Indonesia terkait dengan sistem pendidikan nasional, sistem pelatihan kerja nasional, dan sistem penilaian kesetaraan capaian pembelajaran (learning outcomes) nasional, yang dimiliki Indonesia untuk menghasilkan sumber daya manusia nasional yang bermutu dan produktif. KKNI menyatakan sembilan jenjang kualifikasi sumber daya manusia Indonesia yang produktif. Deskripsi kualifikasi pada setiap jenjang KKNI secara komprehensif mempertimbangkan sebuah capaian pembelajaran yang utuh, yang dapat dihasilkan oleh suatu proses pendidikan baik formal, non formal, informal, maupun pengalaman mandiri untuk dapat melakukan kerja secara berkualitas. Deskripsi setiap jenjang kualifikasi juga disesuaikan dengan perkembangan ilmu pengetahuan, teknologi, atau seni, serta perkembangan sektorsektor pendukung perekonomian dan kesejahteraan rakyat, seperti perindustrian, pertanian, kesehatan, hukum, dan aspek lain yang terkait. Capaian pembelajaran juga mencakup aspek-aspek pembangun jati diri bangsa yang tercermin dalam Pancasila, Undang-Undang Dasar 1945, dan Bhinneka Tunggal Ika yaitu menjunjung tinggi pengamalan kelima sila Pancasila dan penegakan 
hukum, serta mempunyai komitmen untuk menghargai keragaman agama, suku, budaya, bahasa, dan seni yang tumbuh dan berkembang di bumi Indonesia.

\section{Kesimpulan}

Berdasarkan penelaahan data dapat dismpulkan bahwa Pertama, Konsep dasar Epistimologi Program Studi Hukum Ekonomi Syari'ah pada Fakultas Syari'ah dan Hukum UIN Raden Fatah dalam Mengembangkan kajian Ilmiah adalah (1) KKNI dalam empat parameter utama yaitu (a) Ilmu pengetahuan (science), (b) pengetahuan (knowledge), (c) pengetahuan praktis (know-how), (d) keterampilan (skill), (e) afeksi (affection) dan (f) kompetensi (competency). Selanjutnya (2) Ilmu kesyaria'ahan dengan komponen utama ontology, epitimologi, dan aksiologi sebagai konsep dasar Program Studi Hukum Ekonomi Syari'ah dalam Mengembangkan kajian Ilmiah. Komponen ontology yaitu norma- norma yang mengatur tingkah laku yang bersumber kepada al-Qur'an dan As-Sunnah maupun yang bersumber pada ijtihad. Sedangkan komponen epistimologi melalui metode bayani, metode penalaran analogis terhadap konsep yang ada dalam Al- Qur'an dan As- Sunnahdan metode istislahi berlandaskan pada maqasid al-syari'ah. Metode ilmu syari'ah tersistematis dalam kajian ilmu ushul fikih dan ilmu qawaid fikihiyah. Sementara komponenen aksiologi adalah manfaat yang mengandung nilai- nilai untuk memelihara hubungan vertical dan horizontal secara harmonis.

Kedua, Membangun Keselarasan Pembidangan Penelitian pada Program Studi Hukum Ekonomi pada Fakultas Syari'ah dan Hukum diawali dengan kajian historitas perjuangan pemberlakuan nilai syari'ah di Indonesia. Selanjutnya dalam penelaahan penelitian mahasiswa program studi Hukum Ekonomi Syari'ah dapat membangun keselarasan dan perbedaan penelitian dalam tataran filosofis dan aplikasi dalam perbankan, bentuk sistem. Selanjutnya keselarasan dilakukan dalam wadah pengembangan ilmu-ilmu syari'ah pada tataran ontology, epistimologi maupun aksiologi 


\section{Daftar Pustaka}

Ad-Dawalibi, M. M. (n.d.). Al-Madhai Fi Ushul al-Fiqh. Beirut: Dar al-Kitan Jadid. Ali, M. D. (1993). Sikap Negara dalam Mewujudkan Perlindungan hukum bagi Warga Negara. Jakarta: Yayasal Al Hikmah.

al-Qathan, M. (n.d.). AL- Tasyri'wa al-Fiqh fi al- Islam. Muassasah al- Risalah.

Ash-Shidiqi, M. H. (1993). Falsafat Hukum Islam. Jakarta: Bulan Bintang.

Junaidi, H. (2004). Paradigma Ilmu Syariah (Reformasi Program Studi, Kurikulum, dan Kompetensi Alumni). Yogyakarta: Gama Media.

Junaidi, H. (2008). Analisis Pemikiran Dan Aksi Islam Politik H.M. Soeharto. Palembang: Rafah Press.

Ka'bah, R. (2004). Penegakan Syariat Islam di Indonesia. Jakarta: Khairul Bayan. Musa, K. (1989). Al-Madkhal ila Tasyri' al-Islami. Beirut: Muassanah al-Risalah. Nabhan, M. F. (n.d.). al-Madkhal li al-Tasyri'al-Islami. Beirut: Dra al- Shadir.

Warassih, E. (2004). Pranata Hukum, Sebuah Telaah Sosiologis. Semarang: Suryandaru.

Zuahily, W. (1987). Ushul al-Fiqh al-Islami. Beirut: Dar al-Fikr. 